\title{
Comparison Study of Art Therapy and Play Therapy in Reducing Anxiety on Pre-School Children Who Experience Hospitalization
}

\author{
Sri Ramdaniati, Susy Hermaningsih, Muryati \\ Nursing Department of Bandung Health Polytechnic, Ministry of Health, Bandung, Indonesia \\ Email: sri.ramdaniati@yahoo.com
}

Received 22 December 2015; accepted 26 January 2016; published 29 January 2016

Copyright (C) 2016 by authors and Scientific Research Publishing Inc.

This work is licensed under the Creative Commons Attribution International License (CC BY). http://creativecommons.org/licenses/by/4.0/

(c) (i) Open Access

\begin{abstract}
Pain and hospitalization caused a crisis in the child's life. At the pre-school children, the stress of the disease makes children become less able to cope with separation. As a result, many children show anxious behavior though more vague than toddler age children. Various ways have been conducted by nurses to treat anxiety in children, but the most effective types of the intervention have not be found. Types of intervention that can be done are art therapy and play therapy. This study aims to compare the effects of art therapy and play therapy in reducing anxiety on children who experience hospitalization. A quasi-experimental research design with pre-post test two group design is used. The sample was 23 children pre-school age for art therapy group and 25 children for play therapy with sampling techniques performed purposive sampling. Intervention of art therapy and play therapy each performed for 3 days with duration about 30 minutes. Anxiety levels before and after the intervention were measured by using the facial affective scale. The results show that there is a difference in anxiety between before and after the action in the art therapy group $(p=0.00)$ and that there are differences in anxiety before and after the action in the play therapy group (0.00). But statistical tests using Man Whitney $U$ indicate that there is no difference in anxiety levels in pre-school children who do art therapy and play therapy $(p=0.26)$. So, it is concluded that the art therapy and the play therapy can reduce the level of anxiety on pre-school school children that experience hospitalization. Based on these conclusions, it is recommended that the art therapy and the play therapy can be used by nurses and the choice of the intervention should be submitted to the child.
\end{abstract}

\section{Keywords}

Art Therapy, Play Therapy, Pre-School Children, Hospitalization

How to cite this paper: Ramdaniati, S., Hermaningsih, S. and Muryati (2016) Comparison Study of Art Therapy and Play Therapy in Reducing Anxiety on Pre-School Children Who Experience Hospitalization. Open Journal of Nursing, 6, 46-52. http://dx.doi.org/10.4236/ojn.2016.61005 


\section{Introduction}

Hospitalization is a process for reasons of planning or emergency that requires the child to stay in the hospital in order to undergo treatment and medication. Nevertheless, hospitalization remains a major problem and causes anxiety and fear in children [1]. Hospitalization can also cause stress for children related to the change of environment and the status of their health. According to Hockenberry, Wilson and Winkelstein [2], the main thing that can cause stress on the process of hospitalization is the separation of parents, loss of control, and fear of bodily injury and pain. In addition to stress, hospitalization also causes fear and anxiety in children aged 4 - 6 years [3]. If anxiety in children is not addressed, it will result in withdrawal and rejection of the implementation of the medical or nursing action, the length of stay and increase of the severity of health conditions [4].

Various interventions can be done by nurses and parents to overcome anxiety and fear in children, such as creating a pleasant atmosphere, providing support, and giving explanation [5]. Research by Ramdaniati \& Setiawan [6] explains that the play can reduce fear in children. In addition to playing, art therapy is a collection of therapeutic approaches that involve the creative arts. Art therapy programs vary and may include aspect of drawing, painting, photography, sculpture, dancing, creative writing and storytelling [7]. Some research suggests that stress and fear in children can be reduced with the use of the method of drawing [8]. Rollins [9] explains that drawing helps children communicate his experience so as to reduce stress and anxiety. Play therapy is the use of play as a therapy used to reduce distress, and fear in children [10]. According to Armstrong [11], playing for children is not a sheer pleasure, but it is a way to express the anxiety and fear of a situation so clear that any type of game is granted. Decreasing fear and anxiety is meaningful. This study aims to compare the art therapy with the play therapy in reducing anxiety on preschool children who experience hospitalization.

\section{Methods}

A quasi-experimental pretest-posttest two group design was initiated during 3 month period ending 8 October 2015 with a sample size of 48 children pre-school age for both treatment groups. Samples are taken by purposive sampling of pre-school age children who are being hospitalized in Al Islam Bandung Hospital. Inclusion criteria were aged from 3 - 6 years old, the first day of hospitalized and having compos mentis counciosness and the exlusion criteria were children who had limited motion in the upper extremity (not able to move right and left hands to draw or play a puzzle) and children who are pain.

The study was approved by ethical commission of Bandung Health Polytechnic and before the enrolment of this study, the parents received verbal information about the research including procedure, benefit and also gave written informed consent to participate in the study. The research process begins with the selection of the appropriate sample inclusion criteria, then the children are grouped into 2 groups of interventions based on their own choices, namely drawing (art therapy) and puzzles (play therapy). Furthermore, researchers take measurements of anxiety before the intervention using the modified facial affective scale [12] consisting of four images of the face, then intervention for 15 - 30 minutes in a 3-day, after that researcher taking second measurement for identified anxiety level after the intervention. The data collected is then processed and analyzed gradually ranging from univariate continued with bivariate. Univariate analysis using frequency distribution and proportion, while bivariate analysis using wilxocon test for each group and Man Whitney U for measurements both treatment groups with statistical significance difference or $\mathrm{p}$ value below 0.05 .

\section{Result}

Based on Table 1, it can be seen that the average age of children who are respondents in this study is 4.21 years to 4.40 years, with the same age range between 3 to 6 years in accordance with the criteria inclusion that has been set.

Table 2 shows that more than half of the respondents in this group are male and have never been hospitalized.

Table 3 shows that in group play therapy, more than half respondents are male and have never had the experience to be hospitalized.

Table 4 shows that in the group art therapy, children's anxiety levels before treatment are subjected to severe anxiety (43.5\%), followed by moderate anxiety (34.8\%) and mild anxiety $(21.7 \%)$ and none of the respondents who do not experience anxiety. While at the time after treatment, more than half do not experience anxiety and 
Table 1. Frequency distribution of respondent age at the play therapy and art therapy group $(n=48)$.

\begin{tabular}{cccc}
\hline Characteristics Age & Mean & SD & Min-Max \\
\hline Group Art Therapy & 4.21 & 0.99 & 3.0 to 6.0 \\
Group Play Therapy & 4.40 & 1.08 & 3.0 to 6.0 \\
\hline
\end{tabular}

Table 2. Frequency distribution of respondents characteristics at the art therapy group $(n=23)$.

\begin{tabular}{lcc}
\hline Characteristics & F & $\%$ \\
\hline Gender & 14 & 60.9 \\
Male & 9 & 39.1 \\
Female & & 43.5 \\
Treated experience & 10 & 56.5 \\
Ever & 13 & \\
\hline
\end{tabular}

Table 3. Frequency distribution of respondent characteristics at the play therapy group $(n=25)$.

\begin{tabular}{lcc}
\hline Characteristics & F & $\%$ \\
\hline Gender & 14 & 56 \\
Male & 11 & 44 \\
Female & & 28 \\
Eveated experience & 7 & 72 \\
Has never been & 18 & \\
\hline
\end{tabular}

Table 4. Frequency distribution of anxiety levels before and after treatment at the art therapy group $(n=23)$.

\begin{tabular}{|c|c|c|c|c|c|c|c|c|c|c|}
\hline \multirow{3}{*}{ No. } & \multicolumn{10}{|c|}{ Anxiety levels } \\
\hline & \multirow[t]{2}{*}{ Intervention } & \multicolumn{2}{|c|}{ Not anxiety } & \multicolumn{2}{|c|}{ Mild anxiety } & \multicolumn{2}{|c|}{ moderate anxiety } & \multicolumn{2}{|c|}{ Severe anxiety } & \multirow[b]{2}{*}{ Total } \\
\hline & & $\mathrm{F}$ & $\%$ & $\mathrm{~F}$ & $\%$ & $\mathrm{f}$ & $\%$ & $\mathrm{f}$ & $\%$ & \\
\hline 1. & Before & 0 & 0.0 & 5 & 21.7 & 8 & 34.8 & 10 & 43.5 & 23 \\
\hline 2. & After & 12 & 52.2 & 8 & 34.8 & 3 & 13.0 & 0 & 0.0 & 23 \\
\hline
\end{tabular}

none of the respondents who experienced severe anxiety.

Based on Table 5 can be seen that the play therapy group obtained the data that is currently before the treatment more than half of respondents (52\%) had moderate anxiety and no one responden who do not experience anxiety. At the time after treatment, most do not experience anxiety and no one responden experiencing moderate and severe anxiety.

Table 6 shows that, based on analysis by using wilxocon test showed significant differences $(p<0.05)$ between anxiety before and after the action in each group play therapy and art therapy group.

Results of the analysis in Table 7 shows that the statistical test p value $>0.05$, which means that at $5 \%$ alpha there is no significant difference between the level of anxiety in the play therapy and art therapy group by using Man Whitney U Test.

\section{Discussion}

Anxiety is a condition that is often found in children who undergo hospitalization. Almost at every stage of development of the child's age, anxiety and fear due to hospitalization is still a major problem in nursing services subsidiary as disclosed by Ambarwati [13] that hospitalization can cause stress and anxiety at all age levels. For preschool children hospitalization is a frightening experience [14] and Ramdaniati [15] also explained that 53\% of pre-school age children who are undergoing hospitalization experience fear.

Various efforts have been made by caregivers to overcome the problems that arise as a result of hospitaliza- 
Table 5. Levels of anxiety before and after treatment at the play therapy group $(n=25)$.

\begin{tabular}{|c|c|c|c|c|c|c|c|c|c|c|}
\hline \multirow{3}{*}{ No. } & \multicolumn{10}{|c|}{ Anxiety levels } \\
\hline & \multirow[t]{2}{*}{ Intervention } & \multicolumn{2}{|c|}{ Not worried } & \multicolumn{2}{|c|}{ Mild anxiety } & \multicolumn{2}{|c|}{ moderate anxiety } & \multicolumn{2}{|c|}{ Severe anxiety } & \multirow[b]{2}{*}{ Tota } \\
\hline & & $\mathrm{F}$ & $\%$ & $\mathrm{~F}$ & $\%$ & $\mathrm{f}$ & $\%$ & $\mathrm{f}$ & $\%$ & \\
\hline 1. & Before & 0 & 0.0 & 8 & 32.0 & 13 & 52.0 & 4 & 16.0 & 25 \\
\hline 2. & After & 16 & 64.0 & 9 & 36.0 & 0 & 0.0 & 0 & 0.0 & 25 \\
\hline
\end{tabular}

Table 6. Distibution of anxiety levels before and after treatment at the group play therapy and art therapy.

\begin{tabular}{lccc}
\hline Variables & Mean Rank & P Value & $\mathrm{n}$ \\
\hline $\begin{array}{l}\text { Group Play Therapy } \\
\text { Pre Intervention } \\
\text { Post Intervention }\end{array}$ & 12.5 & 0.00 & 25 \\
$\begin{array}{l}\text { Group Art Therapy } \\
\begin{array}{l}\text { Pre Intervention } \\
\text { Post Intervention }\end{array}\end{array}$ & & & \\
\hline
\end{tabular}

Table 7. Differences anxiety levels at the play therapy and art therapy group.

\begin{tabular}{lccc}
\hline Variables & Mean Rank & p Value & $\mathrm{n}$ \\
\hline Play Therapy & 22.60 & & \\
Art Therapy & 26.57 & 0.26 & 48 \\
\hline
\end{tabular}

tion. One of the nursing actions to reduce the impact of hospitalization is playing. For children, play is a routine job. Playing is an activity that is done voluntarily and there is no coercion or pressure from outside or liabilities [16]. Play is a reflection of the ability of physical, intellectual, emotional and social and play a good medium for learning because the children can speak (communicate), learn to adapt to the environment, and do what can be done [17]. Play can be carried by healthy or sick children. Although the child was ill, but there remains a need for play [18].

Games consists of various types and kinds, depending on which side of judgment. In this study, researchers tried to compare the effects between the two games is play therapy and art therapy in reducing anxiety in preschool children. Play therapy is done using a puzzle as media and art therapy for children were asked to draw what she likes in a picture book provided. Selection of the type of game based on the child's own choice. Children choose the type of game he likes. Games that like by the child makes the child feel good about the game, while if the child does not like his game then the child will not enjoy the game.

Based on the results listed in Table 5 in the previous section, the results of the univariate analysis in play therapy showed that $52 \%$ of pre-school children experiencing moderate anxiety at the moment before the game, followed by mild anxiety and no anxiety as much as $32 \%$ and as much as $16 \%$. This condition is changed after the intervention in the form of puzzles for 30 minutes for 3 days. Most children (64\%) had not experienced anxiety and the rest (36\%) experienced only mild anxiety. Then performed bivariate analysis to compare the changes that occur. Results of the analysis in Table 6 in the previous section shows that the play therapy with the use of the puzzle has significant value $<0.05$ at alpha of 0.05 . This means that the play therapy by using puzzles can reduce anxiety levels pre-school age children significantly. The results are consistent with research conducted by Kaluas, Ismanto and Kundre [19] which states that playing puzzle and storytelling can reduce anxiety preschool children who experienced hospitalization at the hospital. Another study also had the same result is research de Breving, Ismanto and Onibala [20] which uses the game as well as an ice cube as one action atraumatic care in children aged 1 - 14 years who experience anxiety. Research results by Hela and Tjahyono [21] in the RS. William Booth Surabaya also support the conclusion that this research through play therapy affect the child's anxiety level with a significance value of 0.00 .

In addition to viewing of the play therapy using puzzzle, this study also looked at the effects of art therapy against anxiety pre-school children. Drawing is a form of art therapy are performed as one of the interventions in 
this study in order to reduce the level of anxiety in the pre-school age children who experience hospitalization. Results of univariate analysis of the results of this group showed that at the time before the intervention, almost half of the respondents had a severe anxiety, followed by moderate and mild anxiety and no one who does not experience anxiety. This condition changed when measurement after intervention demonstrated that no one is experiencing severe levels of anxiety. From the tables can be seen that in descriptive, art therapy can reduce anxiety levels of children. Furthermore, after the bivariate analysis using the Wilcoxon test to compare the conditions before and after the act of art therapy showed that the 0.00 significance value which gives the sense that art therapy can reduce anxiety levels significantly in pre-school age children.

The result of this are in line with research Wowiling, Ismanto and Babakal [22] and Pravitasari and Warsito [23] which uses coloring techniques as a form of art therapy that is performed at pre-school age children in order to reduce anxiety. In the study it was obtained $p$ value of 0.00 which means that the art therapy influence on the anxiety level of pre-school children. Coloring technique drawing on research conducted by Kapti, Ahsan and Istiqomah [24] is also a positive effect on maladaptive behavior of children who experience hospitalization. Meaningfulness use art therapy to reduce children's anxiety in this study are not always in line with the results of previous studies. Purwandari's research [25] explained that the art therapy does not give effect to decrease the level of anxiety in school children but are effective in lowering the pulse rate is one of the physiological response of anxiety. This distinction is made possible because of differences in the age of respondents, where the research Purwandari respondents are school-age children in the 6 - 12 year range, while respondents in this study were pre-school children who still have high levels of anxiety.

The results of the study mentioned above can be analyzed that the drawing as a form of art therapy performed capable of being distractor, expressive space for children as well as a medium of communication that is able to describe the condition of children's anxiety during hospitalization. Besides drawing or coloring can reduce tension, it also giving a relaxing effect on the body and can provide emotional stimuli in the limbic system that occurs in the hypothalamic control of maladaptive behavior, including anxiety responses. Although obviously not be denied the possibility of the influence of the presence of a parent or other factors that contribute simultaneously reduce anxiety in children.

Table 8. Advantages and disadvantages of art therapy and play therapy.

\begin{tabular}{|c|c|c|}
\hline & Advantages & Disadvantages \\
\hline Art Therapy & $\begin{array}{l}\text { - } \\
\text { - } \\
\text { Expressive space for children as well as a medium of } \\
\text { communication that is able to describe the condition of } \\
\text { children's anxiety during hospitalization } \\
\text { - } \quad \text { Also giving a relaxing effect on the body } \\
\text { - Can provide emotional stimuli in the limbic system that } \\
\text { occurs in the hypothalamic control of maladaptive } \\
\text { behavior } \\
\text { - Therapeutic in itself because client gives symbolic } \\
\text { shape and form to feelings } \\
\text { Can serve to express fears which children find too } \\
\text { frightening to talk abou } \\
\text { An active therapy-clients regain sense of control over } \\
\text { healing }\end{array}$ & $\begin{array}{l}\text { - Materials cost money and must be managed. } \\
\text { - } \text { Requires an appropriate setting, especially for fluid } \\
\text { media. } \\
\text { - Some populations (e.g., older adults) may not see the } \\
\text { relevance of artwork to their problem } \\
\text { Requires more planning to incorporate into } \\
\text { information-giving or highly directive counseling modes } \\
\text { - It can not increase ability to explore and practise } \\
\text { children's social skills } \\
\text { It can not help children to make friends and learn about } \\
\text { their ever expanding world }\end{array}$ \\
\hline Play Therapy & $\begin{array}{l}\text { - It provides a safe space for emotional expression } \\
\text { - } \quad \text { helping to empower the child and learn how to express } \\
\text { their thoughts and feelings in constructive ways } \\
\text { - It fosters decision-making and acceptance of } \\
\text { responsibility } \\
\text { It facilitates the development of problem-solving, } \\
\text { coping skills and resilience } \\
\text { - expanding the awareness and self-esteem and increase } \\
\text { the relationship of trust between the patient and health } \\
\text { - } \quad \text { It encourages confidence and concentration } \\
\text { - It fosters imagination and creativity } \\
\text { It supports emotional healing and growth }\end{array}$ & $\begin{array}{l}\text { - Play therapy can be seen as a distraction to the actual } \\
\text { problem. } \\
\text { This type of therapy has positive short term effects, but } \\
\text { it may be harder for the abuse victim later on in life. The } \\
\text { victim may suppress the abuse using play therapy but } \\
\text { eventually the memories will come back as they grow } \\
\text { older (not always, but more often than not) }\end{array}$ \\
\hline
\end{tabular}


In both groups can be seen that at the time before treatment mostly mild to severe anxiety but at the time after the action mostly do not experience anxiety and only a few are experiencing anxiety was, in fact none had severe anxiety. It shows that both therapies together can reduce anxiety in children who are experiencing hospitalization. But when seen from the results of the bivariate analysis in Table 7 can be explained that the value of significance (p value) obtained is 0.26 or greater than 0.05 . This means that there is no significant difference in anxiety levels between the use of art therapy and play therapy in reducing anxiety on pre-school children. Nevertheless, basically the second game can be given to pre-school age children who experience anxiety. Selection of the type of therapy that should be given not based on the opinions of nurses but should be based on the child's favorite, so that they will enjoy the play.

Playing for a child is a necessity. The importance of play, playing techniques as well as efforts to divert attention is to be understood by every nurse. Play can be a psychological preparation efforts for children in the face of a disease that happened and help the process of coping confront actions that will be undertaken. The right play can reduce misunderstanding and fear of child, helping to empower the child, expanding the awareness and self-esteem and increase the relationship of trust between the patient and health care workers [26]. Based on the explanation above and some references [27], art therapy and play therapy have some advantages and disadvantages will show in Table 8.

\section{Conclusions \& Suggestions}

The conclusions that can be drawn from this study are: 1) There is a significant difference in anxiety between before and after the action in the art therapy group; 2) There is a significant difference in anxiety between before and after the action in the play therapy group and 3) There are no significant differences in anxiety in pre-school age children in the art therapy group and the play therapy group.

Based on the above conclusion, nurses who work in the children units can use drawing (art therapy) and puzzles (play therapy) to reduce anxiety in pre-school children who experience hospitalization. The type of the therapy is best left to children to choose to have broad opportunities to express.

\section{References}

[1] Supartini, Y. (2004) Konsep Dasar Keperawatan Anak. EGC, Jakarta.

[2] Hockenberry, M.J., Wilson, D. and Winkelstein, M.L. (2005) Wong's Essentials of Pediatric Nursing. 7th Edition, Elsevier Mosby, St. Louis.

[3] Salmela, M., Salantera, S. and Aronen, E. (2009) Child-Reported Hospital Fears in 4 to 6 Year Old Children. Pediatric Nursing, 35, 269-276.

[4] Shield, L. (2001) A Review of the Literature from Developed and Developing Countries Relating to the Effect of the Hospitalization on Children and Parents. International Nursing Review, 48, 29-37. http://dx.doi.org/10.1046/j.1466-7657.2001.00032.x

[5] Widyasari, F.K. (2009) Terapi Bermain Untuk Anak Normal. http://www.mediaindonesia.com/mediahidupsehat/index.php/read/2009/05/12/1160/13/Terapi-Bermain-Untuk-Anak-N ormal

[6] Ramdaniati, S. and Setiawan, R. (2013) Efektifitas Normative Play Dan Therapeutic Play Terhadap Penurunan Rasa Takut Anak Usia Pra Sekolah Yang Dirawat Di RSUD Dr. Slamet Garut. Jurnal Kesehatan Bhakti Kencana, 3, 322325.

[7] Burns, M.E. and Mechanic, O.J. (2012) Art Therapy. The Monday Life.

[8] Burns, S.D. (2011) Reducing Stress in Hospitalized Children. Medical News Today, Sweden.

[9] Rollins, J.A. (2005) Tell Me about It: Drawing as a Communication Tool for Children With Cancer. Journal of Pediatric Oncology Nursing, 25, 203-221. http://dx.doi.org/10.1177/1043454205277103

[10] Chambers, M.A. (1993) Play as Therapy for The Hospitalized Children. Journal of Clinical Nursing, 2, 349-354.

[11] Armstrong, T.S. and Aitken, H.L. (2000) The Developing Role of Play Preparation in Paediatric Anaesthesia. Paediatric Anaesthesia, 10, 1-4. http://dx.doi.org/10.1046/j.1460-9592.2000.00406.X

[12] Ortigosa Quiles, J.M., García-Banda García, G., Chellew, K., Ponsell Vicens, E., Riquelme Marín, A. and Nicolás Carrasco, M.P. (2013) Identification of Degress of Anxiety in Children with Three-Five Face Facial Scales. Psicothema, 25, 446-451.

[13] Ambarwati, F. and Nasution, N. (2012) Buku Pintar Asuhan Keperawatan BayiDan Balita. Cakrawala Ilmu, Yogya- 
karta.

[14] Samiasih, A. (2007) Pengaruh Terapi Bermain Terhadap Tingkat Kecemasan Anak Usia Prasekolah Selama Tindakan Keperawatan di Ruang Tukman.

http://www.academia.edu/3585452/pengaruh_terapi_bermain_terhadap_tingkat_kecemasan_anak_usia_prasekolah_sel ama_tindakan_keperawatan_di_ruang_tukman

[15] Ramdaniati, S. (2011) Analisis Determinan Kejadian Takut Pada Anak Sekolah Dan Pra Sekolah Yang Menjalani Hospitalisasi Di Ruang Perawatan Anak BLUD Dr. Slamet Garut. Tesis, FIK Universitas Indonesia, Jakarta.

[16] Nurhayatin, Soesanto, E. and Alfiyanti, D. (2010) Gambaran Kecemasan Pada Anak Usia Pra Sekolah Yang Dilakukan Terapi Bermain Bercerita Di Ruang Nusa Indah RS. Bakti Wira Tamtama Semarang. Unpublished.

[17] Hockenberry, M.J. and Wilson, D. (2009) Wong’s Essentials Of Pediatric Nursing. 8th Edition, Elsevier Mosby, St. Louis.

[18] Suryanti, Sodikin and Yulistiani, M. (2011) Pengaruh Terapi Bermain Mewarnai Dan Origami Terhadap Tingkat Kecemasan Sebagai Efek Hospitalisasi Pada Anak Usia Pra Sekolah di RSUD dr. R. Goetheng Tarunadibrata, Purbalingga. Jurnal Kesehatan Samodra Ilmu, 3, 73-80.

[19] Kaluas, I., Ismanto, A.Y. and Kundre, R.M. (2015) Perbedaan Terapi Bermain Puzzle Dan Bercerita Terhadap Kecemasan Anak Usia Pra Sekolah (3-5 Tahun) Selama Hospitalisasi Di Ruang Anak RS. Tk III R.W. Monginsidi Menado. Jurnal Keperawatan, 3.

[20] De Breving, R.M., Ismanto, A.Y. and Onibala, F. (2015) Pengaruh Penerapan Atraumatic Care Terhadap Respon Kecemasan Anak Yang Mengalami Hospitalisasi Di RSU Pancaran Kasih Gmim Manado Dan RSUP Prof. Dr. R. D. Kandou Manado. Jurnal Keperawatan, 3.

[21] Hela, M. and Tjahyono, H.D. (2015) Pengaruh Terapi Bermain Terhadap Kecemasan Anak Yang Mengalami Hospitalisasi Di Ruang Mirah Delima RS. William Booth Surabaya. S1 Keperawatan, 4.

[22] Wowiling, F.E., Ismanto, A.Y. and Babakal, A. (2014) Pengaruh Mewarnai Gambar Terhadap Tingkat Kecemasan Pada Anak Usia Pra Sekolah Yang Mengalami Hospitalisasi Di Ruang Irina E. RSUP. BLU. Prof. Dr. R.D. Kandao. Menado. Jurnal Keperawatan, 2, 1-8.

[23] Pravitasari, A. and Warsito, B.E. (2012) Perbedaan Tingkat Kecemasan Pasien Anak Usia Pra Sekolah Sebelum Dan Sesudah Proses Mewarnai. Jurnal Keperawatan Diponegoro, 1, 16-21.

[24] Kapti, R.E., Ahsan A. and Istiqomah, A. (2013) Pengaruh Bermain Dengan Mewarnai Terhadap Penurunan Skor Perilaku Mal Adaptif Anak Usia Pra Sekolah (3-5 Tahun) Yang Mengalami Hospitalisasi Di RS. Kabupaten Kediri. Jurnal Ilmu Keperawatan, 1, 169-175. http://jik.ub.ac.id

[25] Purwandari, H. (2009) Pengaruh Terapi Seni Dalam Menurunkan Tingkat Kecemasan Anak Usia Sekolah Yang Menjalani Hospitalisasi Di Wilayah Kabupaten Banyumas. Tesis. Program Pasca Sarjana Fakultas Ilmu Keperawatan Universitas Indonesia, Jakarta.

[26] Tanaka, K., Yoshikawa, N., Kudo, N., Negishi, Y., Shimizu, T. and Hayata, N. (2010) A Need for Play Specialist in Japanese Children's Wars. Pediatric Nursing, 22, 31-32.

[27] Councill, T. (2012) Medical Art Therapy with Children. In: Malchiodi, C.A., Ed., Handbook of Art Therapy, 2nd Edition, The Guilford Press, New York, 222-239. 